\title{
Penggunaan Media Interaktif Berbasis Geogebra dan Powerpoint Untuk Meningkatkan Keaktifan dan Hasil Belajar Peserta Didik Pada Materi Pegal di Kelas VIII 1 SMPN 3 Tanete Rilau
}

\author{
Azis \\ Guru Mata Pelajaran Matematika SMPN 3 Tanete Rilau Kabupaten Barru, Sulawesi Selatan \\ azis.ahmadgp@gmail.com
}

\begin{abstract}
Abstrak
Pembelajaran pada abad ke-21 menuntut kesungguhan guru dalam mengelola pembelajaran. Perkembangan dan penggunaan teknologi sangat pesat, mempengaruhi setiap aspek kehidupan termasuk dunia pendidikan, maka guru harus mampu menggunakan media pembelajaran berbasis TIK. Pembelajaran dikatakan berhasil jika guru mampu melibatkan peserta didik secara aktif dalam pembelajaran. Suatu alternatif pembelajaran yang dapat meningkatkan keaktifan peserta didik yaitu dengan memanfaatkan TIK. Guru merancang dan membuat media interaktif berbasis geogebra dan powerpoint. Peserta didik melakukan simulasi materi pelajaran (media geogebra), mendiskusikan contoh soal dan soal latihan (media powerpoint). Selama proses pembelajaran peserta didik bekerjasama, saling membantu, dan saling memotivasi untuk menemukan, memahami dan memecahkan masalah. Penggunaan media interaktif berbasis geogebra dan powerpoint pada pembelajaran persamaan garis lurus memberikan hasil yang baik. Pada aspek proses pembelajaran, aktivitas peserta didik pada siklus III mengalami peningkatan dibandingkan siklus I dan II. Pada aspek hasil belajar terjadi peningkatan rata-rata hasil belajar. Pada siklus I, rata-rata hasil belajar peserta didik adalah 46,8 menjadi 53,3 pada siklus II dan pada siklus III menjadi 81,9. Jumlah peserta didik yang mencapai/melampaui nilai KKM pada siklus III lebih banyak dari siklus I dan II. Pada siklus I ketuntasan hanya $15,8 \%$, meningkat menjadi $40 \%$ pada siklus II dan pada siklus III menjadi $85 \%$.
\end{abstract}

Kata Kunci: keaktifan, media interaktif, geogebra, powerpoint

\section{Pendahuluan}

Pembelajaran pada abad ke-21 saat ini menuntut kesungguhan guru dalam mengelola pembelajaran dalam kelasnya. Pada era sebelumnya guru boleh saja merasa berkuasa dan bangga dengan kemampuannya memberikan penjelasan yang sangat rinci terkait materi pelajaran secara lisan kepada peserta didik, bahkan tanpa menggunakan alat peraga atau media pembelajaran. Akan tetapi dalam era sekarang, abad ke-21, di mana perkembangan dan penggunaan teknologi sudah sangat pesat serta mempengaruhi setiap aspek kehidupan manusia termasuk dalam dunia pendidikan, maka seorang guru tidak boleh menutup diri. la harus mampu menggunakan teknologi untuk mendukung pelaksanaan tugasnya di dalam kelas. Penggunaan teknologi dalam pembelajaran dapat diimplementasikan dalam bentuk penggunaan media pembelajaran berbasis TIK. 
Pembelajaran dalam kelas dapat dikatakan berhasil jika seorang guru mampu melibatkan peserta didik secara aktif dalam setiap aspek kegiatan yang telah dirancangnya. Dan keberhasilan itu akan semakin lengkap jika hasil belajar yang diperoleh peserta didik berada di atas nilai kriteria ketuntasan minimal (KKM) yang telah ditetapkan. Peserta didik akan menunjukkan keaktifan dalam pembelajaran apabila mereka merasa tertantang untuk melakukan sesuatu. Dan untuk memberikan tantangan diperlukan sesuatu yang menarik. Sesuatu yang menarik ini dapat berupa aktivitas pembelajaran ataupun berupa media pembelajaran.

Dalam kurikulum sekolah, salah satu mata pelajaran yang diajarkan adalah matematika. Sampai saat ini matematika masih termasuk kategori mata pelajaran yang kurang disukai. Hal ini disebabkan oleh banyak faktor, diantaranya adalah materi matematika tergolong abstrak, banyak rumus, dan banyak hitung-hitungannya. Atau kemungkinan juga disebabkan oleh situasi pembelajaran yang membosankan, kurangnya alat peraga atau media yang digunakan guru dalam pembelajaran.

Berdasarkan pengalaman peneliti selama mengajarkan mata pelajaran matematika dan hasil analisis skor uji kompetensi pada materi Relasi dan Fungsi menunjukkan bahwa rata-rata skor peserta didik kelas VIII ${ }_{1}$ SMPN 3 Tanete Rilau Kabupaten pada semester ganjil Tahun Pelajaran 2018/2019 adalah 57,00. Hal ini menunjukkan bahwa skor rata-rata peserta didik setelah mengikuti uji kompetensi berada di bawah nilai KKM secara individual yang ditetapkan oleh sekolah yaitu sebesar 78,00. Hal tersebut mengindikasikan bahwa sebagian besar peserta didik memiliki tingkat pemahaman terhadap materi pelajaran masih rendah.

Untuk mengatasi masalah tersebut, diperlukan suatu alternatif pembelajaran yang dapat meningkatkan keaktifan dan hasil belajar peserta didik yaitu dengan menggunakan media interaktif berbasis geogebra dan powerpoint. Model pembelajaran dengan menggunakan media interaktif berbasis geogebra dan powerpoint merupakan suatu model yang memanfaatkan TIK dalam pembelajaran. Peserta didik dalam kelompoknya melakukan diskusi untuk memulai belajar dengan memahami permasalahan dan materi ajar yang tertuang dalam media interaktif berbasis geogebra dan powerpoint. Mereka mendiskusikan materi dengan melakukan simulasi-simulasi dalam media geogebra dan mendiskusikan contoh soal serta soal latihan dalam media powerpoint. Selama proses pembelajaran berlangsung memungkinkan peserta didik untuk bekerjasama, saling membantu, dan memotivasi peserta didik lainnya dalam menemukan dan memahami serta memecahkan permasalahan yang diberikan sehingga pembelajaran betul-betul berpusat pada peserta didik.

\section{Kajian Teori}

Belajar adalah suatu proses perubahan tingkah laku individu melalui interaksi dengan lingkungannya. Belajar yang sebaik-baiknya adalah dengan mengalami sesuatu yaitu menggunakan pancaindra. Jhon Dewey (dalam Koswara, 2008:5) menekankan bahwa belajar adalah apa yang harus dikerjakan siswa untuk dirinya sendiri. Oleh karena itu, inisiatif baru datang dari siswa.

Hasil belajar peserta didik dapat diperoleh guru setelah melakukan proses penilaian dan dinyatakan dengan nilai. Berdasarkan permendikbud No. 53 tahun 2015 penilaian hasil belajr oleh pendidik adalah proses pengumpulan informasi/data tentang capaian pembelajaran peserta didik dalam aspek sikap, aspek pengetahuan dan aspek keterampilan yang dilakukan secara terencana dan sistematis yang dilakukan untuk memantau proses, kemajuan belajar, dan perbaikan hasil belajar melalui penugasan dan evaluasi hasil belajar. Jadi, hasil belajar 
adalah hasil yang didapatkan oleh peserta didik setelah mengikuti proses pembelajaran secara utuh yang diakhiri dengan tes yang ditandai dengan nilai.

Sumantri (2015:13) menjelaskan bahwa kegiatan pembelajaran adalah rangkaian kegiatan yang dirancang untuk memberikan pengalaman belajar yang melibatkan proses mental dan fisik melalui interaksi antarpeserta didik, peserta didik dengan guru, lingkungan, dan sumber belajar lainnya dalam rangka pencapaian kompetensi. Di dalam kegiatan belajar terkandung berbagai kegiatan, seperti: visual, lisan, mendengarkan, menulis, menggambar, metrik, mental, dan emosional. Menurut Riyanto (2012:76) implikasi prinsip keaktifan bagi siswa berwujud perilaku-perilaku seperti mencari sumber informasi yang dibutuhkan, menganalisis hasil percobaan, membuat karya tulis, dan sebagainya.

Berdasarkan Peraturan Menteri Pendidikan Nasional Nomor 24 Tahun 2007 tentang Standar Sarana dan Prasarana, dijelaskan di dalam lampiran bahwa peralatan pendidikan adalah sarana yang secara langsung digunakan untuk pembelajaran. Sedangkan media pendidikan adalah peralatan pendidikan yang digunakan untuk membantu komunikasi dalam pembelajaran. Menurut Sahid (dalam Fadjar Noer Hidayat, 2018), geogebra sebagai alat bantu pembelajaran matematika dapat digunakan dalam berbagai cara, antara lain untuk demonstrasi, simulasi, dan visualisasi, sebagai alat bantu konstruksi, dan untuk eksplorasi dan penemuan matematika.

Pada powerpoint terdapat fasilitas pemberian gambar dan animasi. Memberi gambar pada presentasi pembelajaran dapat membuat presentasi pembelajaran menjadi lebih jelas dan menarik. Gambar memiliki rangkaian ribuan kata dan makna. Selain memberi gambar, penggunaan animasi pada presentasi pembelajaran juga sangat membantu dalam proses pembelajaran. Dengan animasi, pembelajaran menjadi lebih menarik, lebih mudah dalam menunjukkan materi yang sulit dibayangkan.

\section{Metode Penelitian}

Penelitian tindakan kelas ini dilaksanakan dalam tiga siklus dengan mengikuti empat tahapan seperti yang dikemukakan Raka Joni (1988) dalam Wasisto (2016). Keempat tahapan tersebut adalah: (1) perencanaan tindakan; (2) pelaksanaan tindakan; (3) observasi dan interpretasi; dan (4) analisis dan refleksi, kemudian melakukan lagi tahapan-tahapan tersebut pada siklus berikutnya sehingga dicapai sebuah keberhasilan.

Media yang dipergunakan dalam penelitian tindakan kelas ini adalah media interaktif berbasis geogebra dan powerpoint yang merupakan karya orisinil guru. Secara umum materi ajar disajikan dalam bentuk media interaktif powerpoint sedangkan media interaktif geogebra digunakan sebagai media peserta didik untuk mengeksplorasi kemampuannya dalam memahami materi ajar.

Data yang dikumpulkan dalam penelitian tindakan kelas ini ada dua macam, yaitu data proses pembelajaran yang diperoleh dengan menggunakan lembar observasi aktivitas peserta didik dan lembar kuesioner tanggapan peserta didik terhadap penggunaan media interaktif berbasis geogebra dan powerpoint, dan data hasil belajar peserta didik yang diperoleh dengan memberikan tes hasil belajar yang diambil pada akhir siklus I, siklus II, dan siklus III. Data yang terkumpul dianalisis secara deskriptif kualitatif, yaitu data kuantitatif yang diperoleh diolah dengan persentase dan rerata nilai. Selanjutnya, data tersebut diinterpretasikan dengan melihat kecenderungan umumnya untuk mengungkapkan hasil penelitian dengan lebih jelas. Kriteria penarikan kesimpulan mengenai hasil belajar peserta didik sebagai berikut: 
1). Dinyatakan "Berhasil" apabila peserta didik yang telah mencapai nilai Kriteria Ketuntasan Minimal $(\mathrm{KKM})=75$ adalah $80 \%$ atau lebih ( $\geq 16$ orang) dari 20 orang peserta didik.

2). Dinyatakan "Tidak Berhasil" apabila peserta didik yang mencapai nilai Kriteria Ketuntasan Minimal $(\mathrm{KKM})=75$ tidak mencapai $80 \%$ (<16 orang) dari 20 orang peserta didik.

Kriteria keberhasilan kegiatan pembelajaran dari aspek aktivitas peserta didik sesuai dengan kriteria pada tabel berikut.

Tabel 1. Kriteria keberhasilan proses pembelajaran

\begin{tabular}{lll}
\hline No & Kriteria & Kategori \\
\hline 1. & $>75 \%$ peserta didik aktif dalam PBM & Sangat Berhasil \\
2. & $50 \%-75 \%$ peserta didik aktif dalam PBM & Berhasil \\
3. & $25 \%-50 \%$ peserta didik aktif dalam PBM & Kurang Berhasil \\
4. & $<25 \%$ peserta didik aktif dalam PBM & Tidak Berhasil \\
\hline
\end{tabular}

Kriteria ketuntasan belajar secara klasikal berdasarkan penilaian hasil belajar sesuai dengan kriteria pada tabel berikut.

Tabel 2. Kriteria ketuntasan belajar klasikal

\begin{tabular}{lll}
\hline No & Kriteria & Kategori \\
\hline 1. & $>85 \%$ peserta didik mencapai nilai $\geq$ KKM & Sangat Berhasil \\
2. & $80 \%-85 \%$ peserta didik mencapai nilai $\geq$ KKM & Berhasil \\
3. & $65 \%-80 \%$ peserta didik mencapai nilai $\geq$ KKM & Kurang Berhasil \\
4. & $<65 \%$ peserta didik mencapai nilai $\geq$ KKM & Tidak Berhasil \\
\hline
\end{tabular}

Patokan penentuan keberhasilan dalam penelitian tindakan kelas ini sesuai kriteria pada tabel berikut.

Tabel 3. Kriteria keberhasilan penelitian

\begin{tabular}{llll}
\hline No & Proses Belajar Klasikal & Hasil Belajar Klasikal & Predikat Hasil Penelitian \\
\hline 1 & Sangat Berhasil & Sangat Berhasil & Sangat Berhasil \\
2 & Sangat Berhasil & Berhasil & Berhasil \\
3 & Berhasil & Sangat Berhasil & Berhasil \\
4 & Berhasil & Berhasil & Berhasil \\
5 & Berhasil & Kurang Berhasil & Tidak Berhasil \\
6 & Kurang Berhasil & Berhasil & Tidak Berhasil \\
7 & Kurang Berhasil & Kurang Berhasil & Tidak Berhasil \\
8 & Sangat Berhasil & Kurang Berhasil & Tidak Berhasil \\
9 & Kurang Berhasil & Sangat Berhasil & Tidak Berhasil \\
10 & Tidak Berhasil & Tidak Berhasil & Tidak Berhasil \\
\hline
\end{tabular}

\section{Hasil Penelitian}

\section{Data Hasil Observasi Aktivitas Peserta Didik selama Pembelajaran}

Tabel 4. Derajat tanggapan peserta didik pada pembelajaran siklus I

\begin{tabular}{|c|c|c|c|c|c|c|c|c|}
\hline \multirow{2}{*}{ No } & \multirow{2}{*}{ Aktivitas Peserta Didik } & \multicolumn{7}{|c|}{ Derajat Tanggapan Peserta Didik } \\
\hline & & $T$ & $\%$ & $S$ & $\%$ & $\mathbf{R}$ & $\%$ & Jml. \\
\hline 1. & $\begin{array}{l}\text { Perhatian peserta didik pada saat } \\
\text { guru memperkenalkan, membagikan } \\
\text { dan menjelaskan media interaktif }\end{array}$ & 4 & 20 & 11 & 55 & 5 & 25 & 20 \\
\hline 2. & $\begin{array}{l}\text { Keterlibatan peserta didik pada saat } \\
\text { kegiatan eksplorasi kelompok }\end{array}$ & 6 & 30 & 9 & 45 & 5 & 25 & 20 \\
\hline 3. & $\begin{array}{l}\text { Keterlibatan peserta didik pada saat } \\
\text { menjawab LK }\end{array}$ & 8 & 40 & 5 & 25 & 7 & 35 & 20 \\
\hline
\end{tabular}




\begin{tabular}{|c|c|c|c|c|c|c|c|c|}
\hline \multirow{2}{*}{ No } & \multirow{2}{*}{ Aktivitas Peserta Didik } & \multicolumn{7}{|c|}{ Derajat Tanggapan Peserta Didik } \\
\hline & & $\mathbf{T}$ & $\%$ & $\mathbf{S}$ & $\%$ & $\mathbf{R}$ & $\%$ & Jml. \\
\hline 4. & $\begin{array}{l}\text { Keterlibatan peserta didik pada saat } \\
\text { diskusi kelas }\end{array}$ & 10 & 50 & 7 & 35 & 3 & 15 & 20 \\
\hline 5. & $\begin{array}{l}\text { Perhatian peserta didik pada saat } \\
\text { guru memberikan penguatan materi }\end{array}$ & 5 & 25 & 12 & 60 & 3 & 15 & 20 \\
\hline \multicolumn{2}{|c|}{ Jumlah/Tingkat Keterlibatan Peserta Didik } & 33 & 33 & 44 & 44 & 23 & 23 & 100 \\
\hline
\end{tabular}

Tabel 5. Derajat tanggapan peserta didik pada pembelajaran siklus /I

\begin{tabular}{|c|c|c|c|c|c|c|c|c|}
\hline \multirow{2}{*}{ No } & \multirow{2}{*}{ Aktivitas Peserta Didik } & \multicolumn{7}{|c|}{ Derajat Tanggapan Peserta Didik } \\
\hline & & $T$ & $\%$ & $\mathbf{S}$ & $\%$ & $\mathbf{R}$ & $\%$ & $\mathrm{Jml}$. \\
\hline 1. & $\begin{array}{l}\text { Perhatian peserta didik pada saat } \\
\text { guru memperkenalkan, membagikan } \\
\text { dan menjelaskan media interaktif }\end{array}$ & 7 & 35 & 10 & 50 & 3 & 15 & 20 \\
\hline 2. & $\begin{array}{l}\text { Keterlibatan peserta didik pada saat } \\
\text { kegiatan eksplorasi kelompok }\end{array}$ & 9 & 45 & 7 & 35 & 4 & 20 & 20 \\
\hline 3. & $\begin{array}{l}\text { Keterlibatan peserta didik pada saat } \\
\text { menjawab LK }\end{array}$ & 11 & 55 & 7 & 35 & 2 & 10 & 20 \\
\hline 4. & $\begin{array}{l}\text { Keterlibatan peserta didik pada saat } \\
\text { diskusi kelas }\end{array}$ & 14 & 70 & 4 & 20 & 2 & 10 & 20 \\
\hline 5. & $\begin{array}{l}\text { Perhatian peserta didik pada saat } \\
\text { guru memberikan penguatan materi }\end{array}$ & 10 & 50 & 7 & 35 & 3 & 15 & 20 \\
\hline \multicolumn{2}{|c|}{ Jumlah/Tingkat Keterlibatan Peserta Didik } & 51 & 51 & 35 & 35 & 14 & 14 & 100 \\
\hline
\end{tabular}

Tabel 6. Derajat tanggapan peserta didik pada pembelajaran siklus III

\begin{tabular}{|c|c|c|c|c|c|c|c|c|}
\hline \multirow{2}{*}{ No } & \multirow{2}{*}{ Aktivitas Peserta Didik } & \multicolumn{7}{|c|}{ Derajat Tanggapan Peserta Didik } \\
\hline & & $\mathbf{T}$ & $\%$ & $S$ & $\%$ & $\mathbf{R}$ & $\%$ & Jml. \\
\hline 1. & $\begin{array}{l}\text { Perhatian peserta didik pada saat } \\
\text { guru memperkenalkan, membagikan } \\
\text { dan menjelaskan media interaktif }\end{array}$ & 10 & 50 & 7 & 35 & 3 & 15 & 20 \\
\hline 2. & $\begin{array}{l}\text { Keterlibatan peserta didik pada saat } \\
\text { kegiatan eksplorasi kelompok }\end{array}$ & 15 & 75 & 3 & 15 & 2 & 10 & 20 \\
\hline 3. & $\begin{array}{l}\text { Keterlibatan peserta didik pada saat } \\
\text { menjawab LK }\end{array}$ & 10 & 50 & 10 & 50 & 0 & 0 & 20 \\
\hline 4. & $\begin{array}{l}\text { Keterlibatan peserta didik pada saat } \\
\text { diskusi kelas }\end{array}$ & 11 & 55 & 8 & 40 & 1 & 5 & 20 \\
\hline 5. & $\begin{array}{l}\text { Perhatian peserta didik pada saat } \\
\text { guru memberikan penguatan materi }\end{array}$ & 17 & 85 & 2 & 10 & 1 & 5 & 20 \\
\hline \multicolumn{2}{|c|}{ Jumlah/Tingkat Keterlibatan Peserta Didik } & 63 & 63 & 30 & 30 & 7 & 7 & 100 \\
\hline
\end{tabular}

\section{Data Tes Hasil Belajar Peserta Didik pada Akhir Siklus I, II, dan III}

Data hasil belajar peserta didik diperoleh dari tes hasil belajar yang dilaksanakan pada akhir setiap siklus setelah pelaksanaan pembelajaran. Tes ini dilakukan untuk mengetahui tingkat penguasaan peserta didik terhadap materi pelajaran yang telah dipelajari. Alat tes yang digunakan berupa soal uraian yang telah diuji tingkat validitas butir soal dan reliabilitasnya.

Apabila dilakukan analisis statistik Uji-t dengan data berpasangan, data siklus II dipasangkan dengan data siklus III, maka diperoleh nilai t-hitung sebesar -6,055. Nilai tersebut lebih besar 
daripada nilai t-tabel dengan $\propto=0,05$ pada derajat kebebasan (df) 19 sebesar \pm 2,093 (twotail test). Derajat kebebasan ditetapkan berdasarkan jumlah data berpasangan dikurangi dengan $1 ; 20-1=19$.

\section{Data Hasil Pendataan Pendapat Peserta Didik pada Akhir Siklus III}

Rangkuman pendapat peserta didik terhadap terhadap penggunaan media interaktif berbasis geogebra dan powerpoint pada akhir siklus III dapat dilihat pada tabel berikut.

Tabel 7. Hasil pendapat peserta didik terhadap penggunaan media interaktif

\begin{tabular}{|c|c|c|c|c|c|c|c|c|}
\hline \multirow{2}{*}{ No } & \multirow{2}{*}{ Aktivitas Peserta Didik } & \multicolumn{7}{|c|}{ Derajat Tanggapan Peserta Didik } \\
\hline & & $\mathrm{Ya}$ & $\%$ & Ragu & $\%$ & Tidak & $\%$ & Jml. \\
\hline 1. & $\begin{array}{l}\text { Apakah media interaktif } \\
\text { serupa ini pernah Anda } \\
\text { lihat/ ketahui sebelumnya? }\end{array}$ & 4 & 20 & 5 & 25 & 11 & 55 & 20 \\
\hline 2. & $\begin{array}{l}\text { Apakah media interaktif ini } \\
\text { menarik bagi Anda? }\end{array}$ & 19 & 95 & 1 & 5 & 0 & 0 & 20 \\
\hline 3. & $\begin{array}{l}\text { Apakah media interaktif ini } \\
\text { dapat menampilkan } \\
\text { gambaran materi dengan } \\
\text { jelas? }\end{array}$ & 14 & 70 & 6 & 30 & 0 & 0 & 20 \\
\hline 4. & $\begin{array}{l}\text { Apakah Anda dapat } \\
\text { memahami objek yang } \\
\text { ditampilkan media interaktif } \\
\text { ini? }\end{array}$ & 14 & 70 & 6 & 70 & 0 & 0 & 20 \\
\hline 5. & $\begin{array}{l}\text { Apakah pembelajaran } \\
\text { dengan media interaktif ini } \\
\text { lebih menarik dari pada } \\
\text { pembelajaran sebelumnya? }\end{array}$ & 20 & 100 & 0 & 0 & 0 & 0 & 20 \\
\hline 6. & $\begin{array}{l}\text { Apakah Anda memperoleh } \\
\text { pengetahuan baru dari } \\
\text { pembelajaran dengan media } \\
\text { interaktif ini? }\end{array}$ & 20 & 100 & 0 & 0 & 0 & 0 & 20 \\
\hline
\end{tabular}

Berbagai sajian data di atas pada dasarnya telah menggambarkan manfaat/keunggulan penggunaan media interaktif berbasis geogebra dan powerpoint dalam pembelajaran. Akan tetapi agar lebih jelas, sajian data di atas akan dibahs dengan kajian kualitatif dan interpretatif sesuai temuan data.

\section{Pembahasan}

\section{Pembahasan Hasil Siklus I}

Hasil belajar siklus I masih sangat rendah, jauh dari nilai KKM yang ditetapkan sebesar 75 . Nilai rata-rata pada siklus I hanya 46,8 dengan jumlah peserta didik yang mencapai nilai KKM hanya sebanyak 3 orang $(15,8 \%)$ dari 19 orang yang mengikuti tes hasil belajar. Dengan memperhatikan sebaran nilai perolehan peserta didik, maka dapat disimpulkan bahwa tingkat penguasaan materi antarmereka sangat beragam.

Dengan pertimbangan masih terdapat beberapa kekurangan pada proses pembelajaran dan pada hasil belajar, maka penelitian dilanjutkan pada siklus II dengan beberapa rencana perbaikan yaitu penambahan jumlah laptop dan juga jumlah pertemuan ditambah satu kali pertemuan agar tersedia cukup waktu untuk pembahasan contoh soal yang variatif dan soal latihan. 


\section{Pembahasan Hasil Siklus II}

Hasil belajar siklus II masih tergolong rendah meskipun sudah mengalami peningkatan dibandingkan dengan hasil yang dicapai pada siklus I. Nilai rata-rata pada siklus II naik sedikit menjadi 53,3 dengan jumlah peserta didik yang mencapai nilai KKM sebanyak 8 orang (40\%) dari 20 orang yang mengikuti tes hasil belajar. Dengan memperhatikan sebaran nilai perolehan peserta didik, maka dapat disimpulkan bahwa tingkat penguasaan materi antarmereka masih sangat beragam.

Penelitian dilanjutkan pada siklus III dengan beberapa perbaikan yaitu melakukan perubahan jumlah kelompok dan perubahan susunan anggota. Kelas dibagi ke dalam 5 kelompok dengan masing-masing kelompok terdiri dari 4 orang. Keempat orang anggota kelompok diusahakan bersifat heterogen berdasarkan tes hasil belajar siklus II. Kemudian pada masing-masing kelompok dibentuk subkelompok yang anggotanya dua orang. Materi yang didiskusikan adalah materi yang dipelajari pada siklus II dengan penekanan pada pembahasan contoh soal dan soal latihan.

\section{Pembahasan Hasil Siklus III}

Hasil belajar siklus III sudah tergolong memuaskan dengan meningkatnya nilai rata-rata dari 53,3 menjadi 81,9 dengan jumlah peserta didik yang mencapai nilai KKM sebanyak 17 orang (85\%) dari 20 orang yang mengikuti tes hasil belajar. Dengan memperhatikan sebaran nilai perolehan peserta didik yang mencapai dan melampaui nilai KKM, maka dapat disimpulkan bahwa tingkat penguasaan materi antarmereka sudah agak sama.

Hasil analisis statistik Uji-t dengan data berpasangan, data siklus II dipasangkan dengan data siklus III, maka diperoleh nilai t-hitung sebesar -6,055. Nilai tersebut lebih besar daripada nilai t-tabel dengan $\propto=0,05$ pada derajat kebebasan (df) 19 sebesar \pm 2,093 (two-tail test).

Analisis statistik Uji-t tersebut menunjukkan bahwa dengan tingkat kepercayaan 95\% diyakini nilai peserta didik pada siklus II dan siklus III berbeda. Atau dapat dikatakan bahwa terdapat perbedaan antara kedua nilai tersebut. Dengan demikian ditetapkan bahwa secara signifikan pembelajaran dengan menggunakan media interaktif berbasis geogebra dan powerpoint berhasil meningkatkan hasil belajar peserta didik.

\section{Tanggapan Peserta Didik terhadap Media Interaktif dan Pembelajaran}

Berdasarkan hasil pengisian kuesioner tentang media interaktif dan proses pembelajaran yang dilaksanakan dalam penelitian tindakan kelas ini, secara umum peserta didik memberikan tanggapan yang menggembirakan. Peserta didik menyatakan bahwa pembelajaran yang mereka ikuti lebih menarik dibandingkan dengan pembelajaran sebelumnya dan juga mereka menyatakan dapat memahami objek pada media serta mendapat pengetahuan baru dari penggunaan media interaktif tersebut.

Berdasarkan uraian penyajian dan pembahasan di atas, maka diputuskan bahwa:

1. Proses pembelajaran pada siklus II dan siklus III menunjukkan bahwa peserta didik sangat aktif dalam pembelajaran. Sebenarnya pada siklus I peserta didik juga sudah menunjukkan keaktifan dibandingkan dengan pembelajaran sebelumnya yang tidak menggunakan media interaktif. Hasil yang diperoleh pada siklus III menunjukkan bahwa jumlah peserta didik yang aktif baik dengan kategori tinggi maupun sedang sebanayak 93\% untuk semua bentuk aktivitas tanggapan peserta didik. Dengan demikian, berdasarkan kriteria keberhasilan yaitu proses yang melebihi $75 \%$ peserta didik aktif, maka pembelajaran siklus III dikategorikan sangat berhasil. 
2. Pembelajaran siklus III dengan penggunaan media interaktif berbasis geogebra dan powerpoint secara umum telah sukses meningkatkan hasil belajar peserta didik. Hal ini didasarkan pada terpenuhinya nilai KKM oleh 17 orang (85\%) dari 20 orang peserta didik. Secara kelas, capaian tersebut telah memenuhi kriteria keberhasilan penelitian yang telah ditetapkan sebelumnya, yaitu dinyatakan berhasil sebab jumlah peserta didik yang telah melampui KKM 80\% - 85\%.

3. Oleh karena proses pembelajaran dan hasil belajar yang dicapai dalam pembelajaran siklus III berkategori berhasil dan sangat berhasil, maka sesuai dengan kriteria yang ditetapkan sebelumnya, dinyatakan bahwa penelitian tindakan kelas ini dikategorikan berpredikat berhasil.

\section{Kesimpulan}

Pada pembelajaran materi persamaan garis lurus, media interaktif berbasis geogebra dan powerpoint merupakan media yang sangat penting karena dapat mengeksplorasi kemampuan peserta didik melalui simulasi-simulasi grafik. Media ini tergolong mudah dibuat dan sederhana serta mudah dipergunakan peserta didik. Biaya pembuatan hampir tidak ada. Perangkat lunak geogebra adalah jenis perangkat lunak yang dapat diakses secara gratis, sedangkan perangkat lunak powerpoint biasanya telah tersedia ketika kita membeli laptop.

Pada aspek proses pembelajaran, aktivitas peserta didik pada siklus III mengalami peningkatan dibandingkan pada siklus I dan siklus II. Secara umum semua peserta didik ikut terlibat dalam proses pembelajaran yang menggunakan media interaktif berbasis geogebra dan powerpoint.

Pada siklus I, rata-rata hasil belajar peserta didik adalah 46,8 meningkat menjadi 53,3 pada siklus II dan akhirnya, pada siklus III meningkat menjadi 81,9. Nilai tertinggi relatif tidak berubah pada ketiga siklus yaitu nilai 100, Demikian pula dengan nilai terendah, nilai 10 pada siklus I menjadi 17 pada siklus III. Peserta didik yang memperoleh nilai terendah pada siklus II dan siklus III adalah subyek yang sama, dan setelah ditelusuri peserta didik ini mengalami keterlambatan dalam pemahaman terutama dalam hal operasi hitung sehingga dibutuhkan penanganan khusus dalam bentuk bimbingan khusus di luar penelitian ini.

Jumlah peserta didik yang mencapai dan melampaui nilai KKM pada siklus III lebih banyak dari siklus I dan siklus II. Pada siklus I ketuntasan hanya 15,8\%, meningkat menjadi $40 \%$ pada siklus II dan meningkat lagi pada siklus III menjadi $85 \%$ atau 17 orang dari 20 orang yang mengikuti tes akhir siklus III.

Hasil uji-t menunjukkan bahwa nilai t hitung sebesar -6,055 lebih besar daripada nilai t-tabel sebesar 2,093 pada tingkat kepercayaan 95\%. Hal ini berarti terdapat perbedaan antara hasil belajar siklus III dengan hasil belajar siklus II.

Berdasarkan aktivitas peserta didik dalam pembelajaran yang tinggi dan hasil belajar yang meningkat serta ketuntasan kelas yang sangat baik, maka penelitian tindakan kelas ini dinyatakan berhasil. Semoga penelitian tindakan kelas ini bermanfaat dan menjadi inspirasi bagi guru-guru dalam melakukan inovasi dalam pembelajaran.

\section{Saran}

Disarankan kepada guru mata pelajaran matematika dan juga guru mata pelajaran lainnya, diharapkan dapat melakukan hal-hal berikut: 
1. Membuat dan menggunakan media interaktif dalam pembelajaran untuk memberikan pengalaman belajar yang menyenangkan bagi peserta didik.

2. Melakukan inovasi dan modifikasi media pembelajaran yang ada agar dapat dimanfaatkan sesuai kebutuhan.

3. Membuat dan menggunakan media interaktif lainnya untuk pembelajaran materi pelajaran yang sesuai.

\section{Referensi}

Agus, M. (2018). Meningkatkan Hasil Belajar Geografi Siswa Kelas-X IPS-4 SMA Negeri 3 Palopo melalui Eksperimen Inovatif. Naskah Lomba Inobel Level Utama bagi Guru Jenjang Pendidikan Menengah Tingkat Nasional.

Arikunto, S. (1999). Dasar-Dasar Evaluasi Pendidikan. (Edisi Revisi). Jakarta: Bumi Aksara. Departemen Pendidikan Nasional. 2008. Kamus Besar Bahasa Indonesia Pusat Bahasa. Edisi IV. Jakarta: PT Gramedia Pustaka Utama.

Departemen Pendidikan Nasional. (2004). Materi Pelatihan Terintegrasi. Matematika 3. Jakarta: Bagian Proyek Pengembangan Sistem dan Pengendalian Program SLTP.

Furchan, A. (2011). Pengantar Penelitian dalam Pendidikan. (Karya Donald Ary, Luchy Cheser Jacobs, Asghar Eazavieh). Yogyakarta: Pustaka Pelajar.

Hamalik, O. (2014). Kurikulum dan Pembelajaran. Jakarta: PT Bumi Aksara.

Hamzah, A., Muhlisrarini. (2014). Perencanaan dan Strategi Pembelajaran Matematika. Jakarta: PT RajaGrafindo Persada.

Hidayat, F. N., Marfuah. (2018). Geogebra. Modul Diklat Pemanfaatan TIK untuk Guru Matematika. Yogyakarta: PPPPTK Matematika.

Koswara, D., Deni, \& Halimah. (2008). Bagaiman Menjadi Guru Kreatif? Bandung: PT Pribumi Mekar.

Purnomo, J., Sutrisno, A. (2018). Powerpoint untuk Pembelajaran Matematika. Modul Diklat Pemanfaatan TIK untuk Guru Matematika. Yogyakarta: PPPPTK Matematika.

Riyanto, Y. (2012). Paradigma Baru Pembelajaran. Sebagai Referensi bagi Pendidik dalam Implementasi Pembelajaran yang Efektif dan Berkualitas. Jakarta: Kencana Prenada Media Group.

Sriyono. (1992). Teknik Belajar mengajar dalam CBSA. Jakarta: PT Rineka Cipta.

Sujadi, I., Dhoruri, A. (2016). Guru Pembelajar Modul Matematika SMP. Kelompok Kompetensi B Teori Belajar, Himpunan, dan Logika Matematika. Jakarta: Dirjen GTK Kemendikbud.

Sumantri, M. S. (2015). Strategi Pembelajaran. Teori dan Praktik di Tingkat Pendidikan Dasar. Jakarta: PT RajaGrafindo Persada.

Suryosubroto, B. (2009). Proses Belajar Mengajar di Sekolah. Jakarta: PT Rineka Cipta.

Warso, A. W. D. D. (2016). PKB Publikasi IImiah. PTK dan Nilai Angka Kreditnya. Yogyakarta: Pustaka Pelajar. 